\title{
SELECTION OF NATURE-BASED SOLUTIONS TO IMPROVE COMFORT IN SCHOOLS DURING HEAT WAVES
}

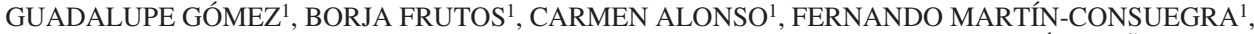 \\ IGNACIO OTEIZA ${ }^{1}$, FERNANDO DE FRUTOS ${ }^{1}$, MARTA M. CASTELLOTE ${ }^{1}$, JESÚS MUÑOZ ${ }^{2}$, \\ SALUSTIANO TORRE 2 , JOSE FERMOSO 3 , TEBA TORRES ${ }^{3}$, MIGUEL A. ANTÓN ${ }^{4}$, \\ TERESA BATISTA ${ }^{5} \&$ NUNO MORAIS ${ }^{6}$ \\ ${ }^{1}$ IETcc-CSIC (Instituto Eduardo Torroja de Ciencias de la Construcción-CSIC), Spain. \\ ${ }^{2}$ RJB-CSIC (Real Jardín Botánico-CSIC), Spain. \\ ${ }^{3}$ Centro Tecnológico CARTIF, Spain. \\ ${ }^{4}$ Área de Desarrollo Rural y Sostenibilidad. Diputación de Badajoz (DIPBA), Spain. \\ ${ }^{5}$ CIMAC (Comunidade Intermunicipal de Alentejo Central), Portugal. \\ ${ }^{6}$ Câmara Municipal do Porto, Portugal.
}

\begin{abstract}
Climate change impacts particularly affect vulnerable populations such as children. Therefore, addressing the adaptation of educational buildings is crucial in avoiding these negative effects on school performance. In this paper, three educational buildings, located in Badajoz (Spain), Evora (Portugal) and Porto (Portugal), serve as pilot samples to study the suitability of nature-based solutions (NBS), chosen for each one of three climatic zones. The NBS selected include green roofs, vertical structures with vegetation to shade holes, outdoor trees and free-cooling ventilation. The scenarios of the different NBS implemented in the three models were simulated with the software EnergyPlus, which allows optimising the appropriate decision before renovation operations begin. The results obtained from the simulations suggest energy performance improvements after applying the most adequate NBS selection to each one of the three buildings tested. Particularly, a reduction in radiation on both roofs and facades is required in the case of Evora and Badajoz, where both climate zones have similar features, that is, warm and dry. While in Porto, milder and more humid than the former ones, it is very effective to operate mainly on the roof, complemented by small ventilation operations.
\end{abstract}

Keywords: climate educational buildings, energy efficiency, heatwaves, indoor environmental quality, nature-based solutions.

\section{INTRODUCTION}

Climate change is now recognised as one of the most serious environmental, social and economic challenges facing the world. Many of the global risks from climate change are concentrated in urban areas. The impacts of climate change, such as heat waves or changes in annual and seasonal rainfall patterns, are particularly affecting the health of vulnerable population, such as children, who spend a third of their lives inside schools [1]. The adaptation of school buildings to climate change would prevent its negative impacts on children's academic performance [2].

Previous research carried out by monitoring, for 1 year, the indoor environmental quality of three schools in Madrid, stated that only $30 \%$ of the teaching hours reached adequate indoor hygrothermal conditions. Adequate air quality was achieved during $64 \%$ of those hours [3]. Following this research trend, the work presented here is part of an ongoing project, LIFE myBUILDINGisGREEN (LIFE17 CCA/ES/000088 - LIFE mBiG), that focuses on educational centres located in Southern Europe. It aims to implement green passive measures, nature-based solutions (NBS) inspired and supported by nature, to improve the resilience of these buildings under new climate conditions caused by global warming. 
The application of NBS in urban environment demonstrates a significant improvement in human resilience and well-being in cities during increasingly hot summers [4, 5]. A wide characterisation of different options of NBS implementation is available both for urban and built environments [6].

Passive measures contribute, in most cases, to the reduction of indoor temperature and energy consumption [7] and improvisation of air quality [2,8]. National and international regulations offer many options and guidelines for the design of different ventilation protocols $[9,10]$. Indoor $\mathrm{CO}_{2}$ concentration over and above the outdoor value is widely used to assess the air quality considered [11, 12]. Standards ISO 17772, EN 16798, EN 15251, ASHRAE 62.1 and ISHRAE 10001 recommend different $\mathrm{CO}_{2}$ ceilings relative to the environmental level [13]. The criterion used to assess air quality in Spanish legislation for residential buildings [14] is that "Habitable rooms in dwellings must be provided by a sufficient flow of outside air to ensure that the mean yearly $\mathrm{CO}_{2}$ concentration is under $900 \mathrm{ppm}$ and the cumulative yearly concentration in excess of $1600 \mathrm{ppm}$ is less than $500,000 \mathrm{ppm} \cdot \mathrm{h}$ ".

The assessment of the impact of green roof design options on the energy performance of buildings has been developed since 2008 through energy models introduced to the EnergyPlus simulation software [15]. Studies suggest that green roofs can lower indoor air temperatures by $1.5-3{ }^{\circ} \mathrm{C}$ depending on the external climate conditions and physical composition of the green roof, and this can be amplified when combined with ventilation during the night [16]. Based on the impact on the energy performance of buildings, certain studies have addressed multi-criteria decision models for green roofs installation, such as the MACBETH method (measuring attractiveness by a categorical-based evaluation technique) developed by Teotónio et al. [17], that can determine the best trade-off option by assessing costs and benefits.

For the case of green facades, Morakinyo et al. [18] use results from validated ENVI-met model simulations and parametric studies to determine how much greening is beneficial for daytime urban cooling and heat island mitigation. For the high-density Hong Kong, $1{ }^{\circ} \mathrm{C}$ temperature drop requires $30-50 \%$ of greened façade ratio. The effect inside buildings can be studied by simplified green wall models using available software for transient thermal simulation of buildings such as EnergyPlus ${ }^{\mathrm{TM}}$, to anticipate future implications of current decisions [19].

Previous studies have analysed the effects of NBS implementation on comfort and energy demand through energy simulations applied to an educational building according to the local climate [20]. The cooling effects mainly depend on shading, whereas a lower proportion was due to transpiration and insulation provided by the direct greenings, which reduce radiation during night-time [21]. The solar permeability has been studied using building performance simulation tools to define the shadows masks of trees [22]. By integrating the data of sap flow rate collected from trees into a building modelling simulation, Hsieh et al. [23] combined environmental real-time data and building energy prediction modelling to understand the specific mechanisms of how trees affect building energy use, concluding that tree shading at a building's west wall can produce the largest energy reduction (up to 50\%) depending on the climate zone and building features, followed by southeast and east walls. In the same study, evapotranspiration reduced the cooling load by $12.4 \%$ during the daytime compared to a treeless scenario, by reducing outdoor temperature. However, the link between NBS selection and condition improvement, according to specific climate, is not sufficiently documented. The research presented here aims to apply shading coefficients obtained by the application of different NBS to three real study cases located in different Mediterranean climatic zones. 


\section{MATERIALS AND METHODS}

This research compares predicted impacts of NBS implementation, in terms of comfort and energy savings for warm periods, to three educational buildings located in different climate regions in Portugal and Spain. An energy simulation tool was used for generating models of the buildings that were calibrated and adjusted with a 1-year monitored data. Subsequently, the models were used for studying the better suited NBS for each building consisting in green roofs and the shading of the facades using the prototypes developed in LIFE mBiG Project, which is described in greater detail in Section 2.4. The effect of NBS on the reduction of cooling demand and indoor temperature under summer conditions is analysed.

\subsection{Pilot case studies: Badajoz, Evora and Porto}

The three schools selected as "livings laboratories" are located in Badajoz (Spain), Evora (Portugal) and Porto (Portugal) (Fig. 1).

The pilot schools share the following construction characteristics:

- Year of construction prior to adoption of the Spanish thermal standard regulation (NBECT-79) [24], in the case of Spain and its Portugal equivalent (Decreto-Lei n. $\left.{ }^{\circ} 40 / 90\right)$ [25].

- Flat roof in good condition for allowing green roof implementation with low-cost intervention.

- Facades in good condition that allow the anchoring of green shading solutions.

\subsection{Climate zones characteristics}

The characteristics of the three climate zones studied are described in Table 1. A software version of the Psychometric Abacus [26], developed by UCLA (Climate Consultant v6), has been used to support the analysis of comfort parameters and the proposal of passive improvement solutions for the three climatic zones. The temperature and relative humidity are represented for each hour of the summer. The different regions of the abacus where these conditions are plotted, lead to adopting appropriate passive strategies to achieve comfortable conditions (as seen in Fig. 2). By implementing them, it should be possible to reduce the use of active systems during the summer, to achieve almost $100 \%$ comfort hours.
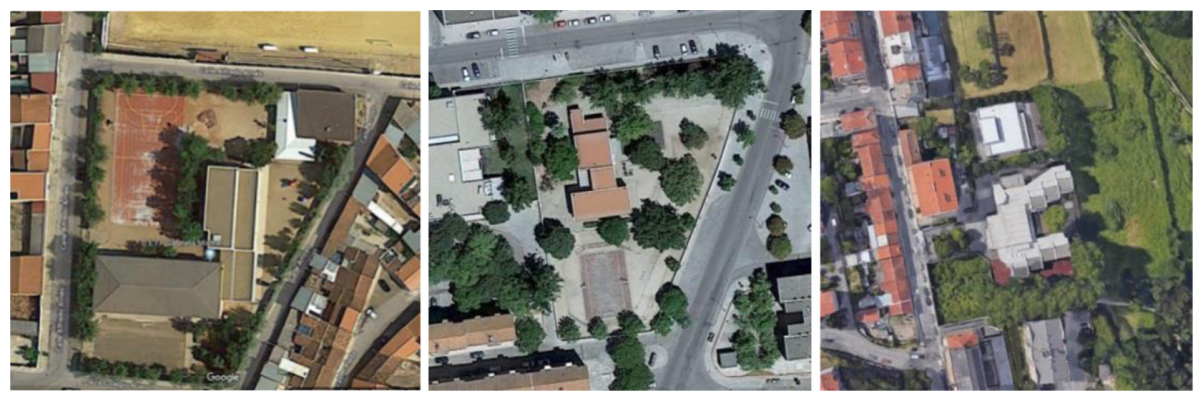

Figure 1: (a) School in Solana de los Barros, Badajoz, Spain. (b) School in Horta das Figueiras, Evora, Portugal. (c) School in Mello Falcão, Oporto, Portugal. (Source: Google Maps). 
Table 1: Main aspects of the three climatic zones studied. Source: https://es.weatherspark.com.

\begin{tabular}{|c|c|c|}
\hline Location & Summer & Winter \\
\hline Badajoz & $\begin{array}{l}\text { Hot and dry. } \\
\text { Lasts } 3.0 \text { months, } \\
\text { (June } 14-\text { September } 13 \text { ). } \\
\text { Average daily max. temp }>30^{\circ} \mathrm{C} \\
\text { Hottest day, July } 29 . \text { Max. } 35^{\circ} \mathrm{C} \text {, } \\
\text { min. } 18^{\circ} \mathrm{C} \text {. }\end{array}$ & $\begin{array}{l}\text { Cool and partly cloudy. } \\
\text { Lasts } 4 \text { months, } \\
\text { (November } 16-\text { March } 4 \text { ). } \\
\text { Average daily max. temp }<18{ }^{\circ} \mathrm{C} \text {. } \\
\text { Coldest day, January } 18 . \text { Min. } 3^{\circ} \mathrm{C} \text {, } \\
\text { max. } 14^{\circ} \mathrm{C} \text {. }\end{array}$ \\
\hline Evora & $\begin{array}{l}\text { Hot and dry. } \\
\text { Lasts } 2.9 \text { months, } \\
\text { (June } 18-\text { September } 13 \text { ). } \\
\text { Average daily max. temp. }>29^{\circ} \mathrm{C} \text {. } \\
\text { Hottest day, July } 29 . \text { Max. } 33^{\circ} \mathrm{C} \text {, } \\
\text { min. } 16^{\circ} \mathrm{C} \text {. }\end{array}$ & $\begin{array}{l}\text { Cool and partly cloudy. } \\
\text { Lasts } 3.7 \text { months, } \\
\text { (November } 15-\text { March } 6 \text { ). Average } \\
\text { daily maximum temperature }<17^{\circ} \mathrm{C} \text {. } \\
\text { Coldest day: January } 18 . \text { Min. } 5^{\circ} \mathrm{C} \text { and } \\
\text { max. } 13^{\circ} \mathrm{C} \text {. }\end{array}$ \\
\hline Porto & $\begin{array}{l}\text { Humid and temperate. } \\
\text { Average min. } 15^{\circ} \mathrm{C} \text { to a max. of } \\
24^{\circ} \mathrm{C} \text {. } \\
\text { Lasts } 3.1 \text { months, } \\
\text { (19 June- } 24 \text { September). } \\
\text { Hottest day, July } 29 \text { th. Max. } 24^{\circ} \mathrm{C} \text {, } \\
\text { min. } 15^{\circ} \mathrm{C} \text {. }\end{array}$ & $\begin{array}{l}\text { Winter not too cold. Prolonged rain. } \\
\text { Average min. of } 6^{\circ} \mathrm{C} \text { and max. } 16^{\circ} \mathrm{C} \text {. } \\
\text { Lasts } 3.5 \text { months, } \\
\text { ( } 22 \text { November-6 March). } \\
\text { Coldest day, January } 24 \text { th. Min. } 6^{\circ} \mathrm{C} \text {, } \\
\text { max. } \\
14^{\circ} \mathrm{C} \text {. }\end{array}$ \\
\hline
\end{tabular}

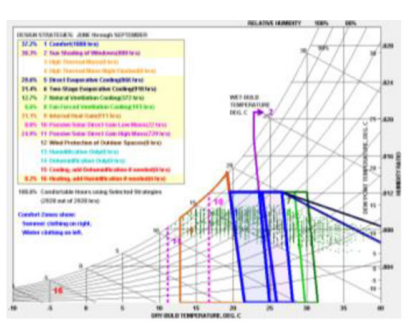

(a)

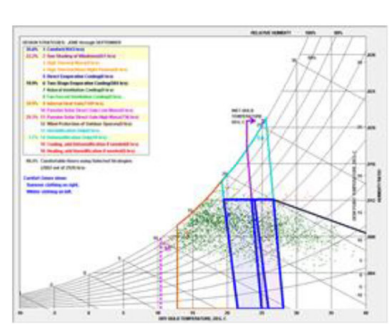

(b)

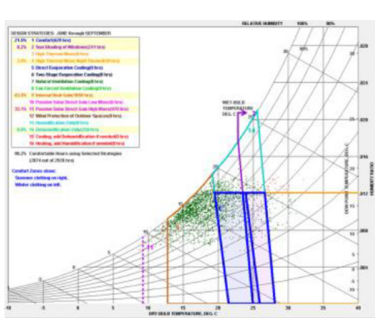

(c)

Figure 2: Psychrometric Abacus including passive improvement measures for summer months in (a) Badajoz (b) Evora and (c) Porto. (Source: Climate Consultant. Department of Architecture and Urban Design. UCLA 2018).

In Table 2, the most recommendable solutions, to achieve comfort zone in each climate, are described. It may be noted that, in general terms, the recommended solutions for dry and warm climates point to radiation protection, evaporative cooling and night ventilation as a complement to provide free cooling. In Porto, with wet climate and not so warm, shading outdoors is not recommended, but windows protection is found appropriate for avoiding overheating. In all three cases, thermal inertia control is recommended as a thermal regulatory mechanism and reflective roofs for reducing radiation gains.

Outdoor climate condition was monitored over a 1-year period. During the months for which no records were collected, data from AEMET (http://www.aemet.es) and WEATHER UNDERGROUND (https://www.wunderground.com) were used. Figure 3 shows the outdoor 
Table 2: Passive improvement solutions recommended for each climate, to achieve comfort zone. Determined by the psychometric diagrams.

\begin{tabular}{lll}
\hline BADAJOZ & EVORA & PORTO \\
\hline $\begin{array}{l}\text { Flat reflective roof } \\
\begin{array}{l}\text { Shaded outdoor spaces and } \\
\text { courtyards }\end{array}\end{array}$ & $\begin{array}{l}\text { Flat reflective roof } \\
\text { Shaded outdoor spaces and } \\
\text { courtyards }\end{array}$ & Flat reflective roof \\
$\begin{array}{l}\text { Windows shading (maximum } \\
\text { in summer and minimum in } \\
\text { winter) }\end{array}$ & $\begin{array}{l}\text { Windows shading (maximum } \\
\text { winter) }\end{array}$ & $\begin{array}{l}\text { Window shading to } \\
\text { prevent overheating }\end{array}$ \\
$\begin{array}{l}\text { Evapourative cooling systems } \\
\text { Thermal inertia inclusion }\end{array}$ & $\begin{array}{l}\text { Evapourative cooling systems } \\
\text { Thermal inertia inclusion }\end{array}$ & $\begin{array}{l}\text { Air dehumidification } \\
\text { Thermal inertia inclu- } \\
\text { Cross ventilation }\end{array}$ \\
$\begin{array}{l}\text { Night ventilation } \\
\text { Internal load management }\end{array}$ & $\begin{array}{l}\text { Cross ventilation } \\
\text { Use of ceiling fans }\end{array}$ & Cross ventilation \\
\hline
\end{tabular}

None of the proposed strategies should negatively influence the bioclimatic behaviour of the building in winter.

temperatures from different databases: A standard year, US Department of Energy's Energy Plus Weather (EPW) database; 2019 and 2020 AEMET records for Badajoz; 2020 WUNDERGROUND records for Porto and the outdoor sensor readings from October to December 2019 for Badajoz and 2020 for Evora. The red line in the middle of Fig. 3 indicates the months from May to September during which heat waves were identified and to which the present detailed study is limited.

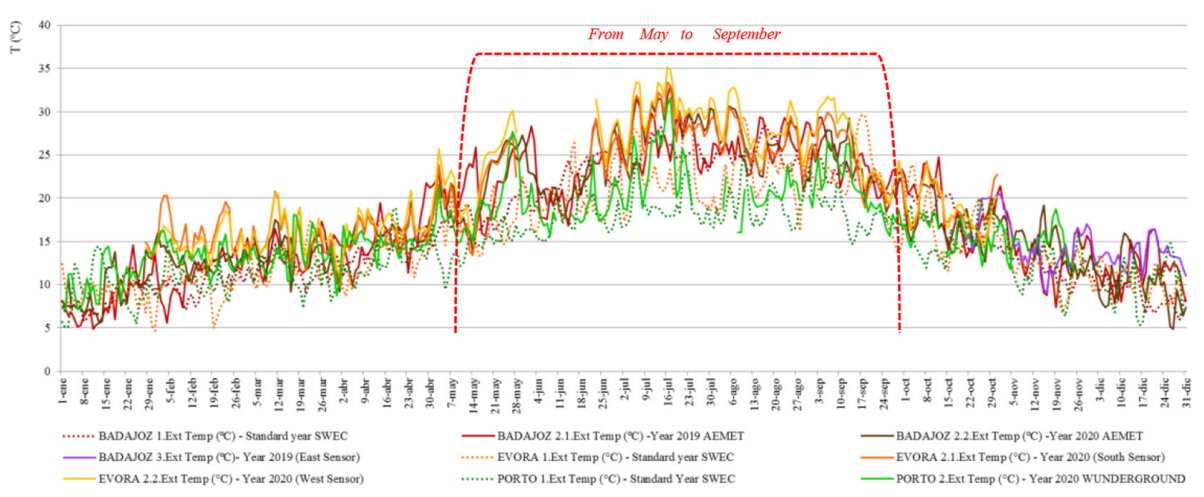

Figure 3: Outdoor daily temperatures for a full year. Badajoz: (1) data from a standard year (source: US DOE), (2.1 and 2.2) data from 2019 and 2020 (source: AEMET), (3) monitored data - East façade - from October to December 2019 (source: authors' data); Evora: (1) data from a standard year (source: US DOE), (2.1 and 2.2) monitored data (source: authors'formulation); Porto: (1) data from a standard year (source: US DOE), (2) data from 2020 (source: WUNDERGROUND). 
As shown previously, the temperatures considered as standard for the three locations offer a clear range of three levels, the highest being for Badajoz, the case of Evora is intermediate and milder for the case of Porto. All of them are below the current temperatures observed in the year monitored for each location.

Data monitored for Badajoz in 2019 show higher temperatures throughout the year than data from a standard year (average data from the past 10 years). In particular, a higher incidence of heat waves is observed. Outdoor temperature peaks can be identified as heat waves that took place during the months of May, July and August 2019. It can also be seen that the data collected in Badajoz by AEMET for 2019 are less than that those collected for 2020. This is a clear indicator of the increase in temperatures from 1 year to the next and how especially high they have been in 2020. It can be seen that the data from sensors located outside for the Western orientation are greater than those for the Southern orientation. Consistent with the fact of more accumulated radiation during the hours of the days, the former appears to be the most critical orientation. It can also be observed that this phenomenon is higher in Evora. In Porto, even with temperatures below Badajoz and Evora, the values for the year 2020 are also higher than the data for a standard year and peaks produced by the heat waves in warm months can be observed as well.

\subsection{IAQ monitored data}

Testo 160 IAQ data loggers were used for monitoring indoor parameters, such as temperature, relative humidity, $\mathrm{CO}_{2}$ concentration and barometric pressure. The sensor characteristics are as follows: temperature accuracy is $\pm 0.5^{\circ} \mathrm{C}$ and resolution is $0.1{ }^{\circ} \mathrm{C}$. Relative humidity accuracy is $\pm 3 \%$ and resolution is $0.1 \% \mathrm{RH}$. $\mathrm{CO}_{2}$ concentration accuracy is $\pm 3 \%$ and resolution is $1 \mathrm{ppm}$. Data loggers are programmed for 15 -minute periods.

The location of the sensors is as follows:

Badajoz - six indoor sensors: one in the old building (to which there is no intervention) used as a reference, two on the ground floor and three on the first floor.

Evora - five sensors: three on the ground floor and two on the first floor.

Porto - six sensors: three on the ground floor and two on the upper floor.

The monitored data show high temperatures inside the classrooms, with several $32{ }^{\circ} \mathrm{C}$ peaks in Badajoz and Evora, and close to $30^{\circ} \mathrm{C}$, in the case of Porto.

Indoor temperatures were analysed in order to determine discomfort hours.

No student occupation was reported during monitoring. Furthermore, there was no ventilation from May to September. Teaching hours are from 9:00 a.m. to 3:00 p.m., from Monday to Friday. The months of July and August are not considered as a teaching period.

Official guidelines established by the Instituto Nacional de Seguridad y Salud en el Trabajo [27] have been used to evaluate comfort levels. A maximum temperature of $27^{\circ} \mathrm{C}$ is set for sedentary work performed in an office. This value is taken as a reference for this research during the months of May, June and September. It is represented by horizontal line in Fig. 4, thus allowing the identification of hours without comfort during these periods.

Monitoring data were not available for Porto, due to problems with the wireless connection. Therefore, data on hours of discomfort are obtained from the simulation of the reference classroom, trying to reproduce the conditions of the monitoring period analysed, for the chosen school months, with an occupation of 0.3 . 


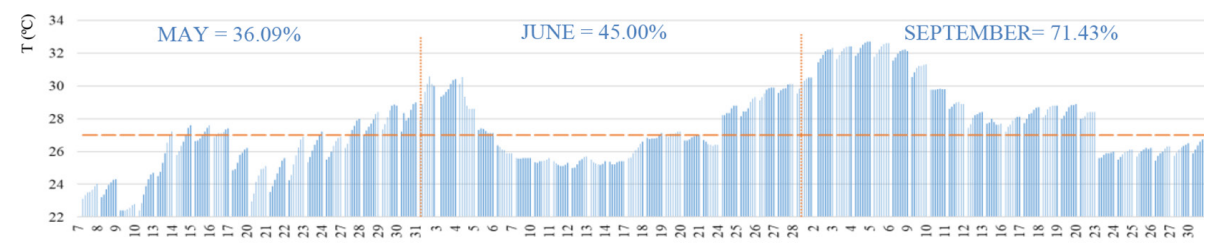

(a)

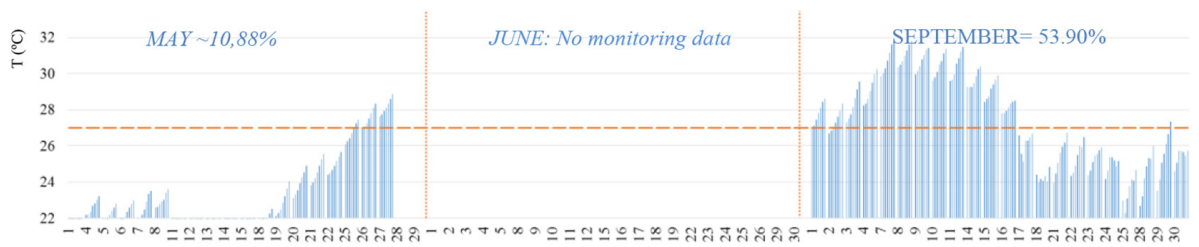

(b)

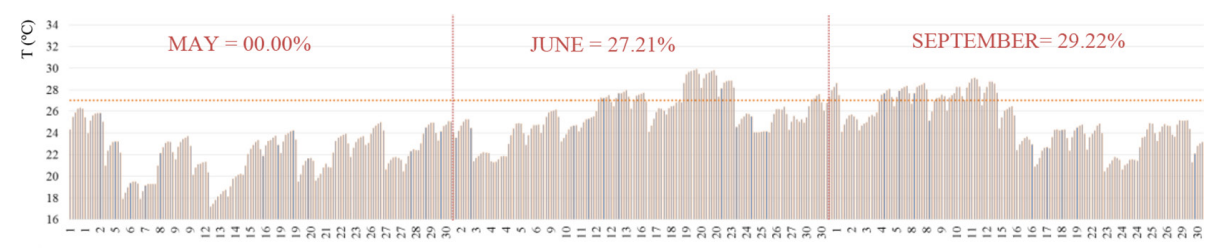

(c)

Figure 4: Hours without comfort within the teaching period. From 9:00 a.m. to 3:00 p.m., from Monday to Friday, during May, June and September. Monitored data of the reference classroom for Badajoz (a), Evora (b) and Porto (c). (Source: authors' formulation).

\subsection{Simulation energy models}

Design Builder (version 4.7) was used as energy simulation tool. This program, which works with the EneryPlus calculation engine, provides dynamic thermal behaviour. In this case, some reference classrooms have been simulated under their actual condition and in their climate location. In the models, standard year climates are used for the three locations' year (US DOE EPW). Comparison of the standard year temperatures with those simulated is presented in Fig. 5.

As shown in Fig. 5, schools located in Evora and Badajoz have greater difficulties in staying below an acceptable comfort temperature, set at $27^{\circ}$, with extreme peaks concentrated in June and September. In the case of Porto, the average is below this comfort limit, although some exceptions can be seen when the analysis is done hour by hour by referring to Fig. 4c.

For the calibration operation, the models were set at educational activity template "Teaching areas which include classrooms and corridors providing access to and between classrooms". Occupation is not considered since the monitored classroom was unoccupied during the tested period. After adjustment and calibration, the implementation of NBS solutions were simulated as indicated in Fig. 6. An educational occupation profile was applied. Teaching hours are considered from 9:00 a.m. to 3:30 p.m. from Monday to Friday, being "Off" on Saturdays and Sundays. 


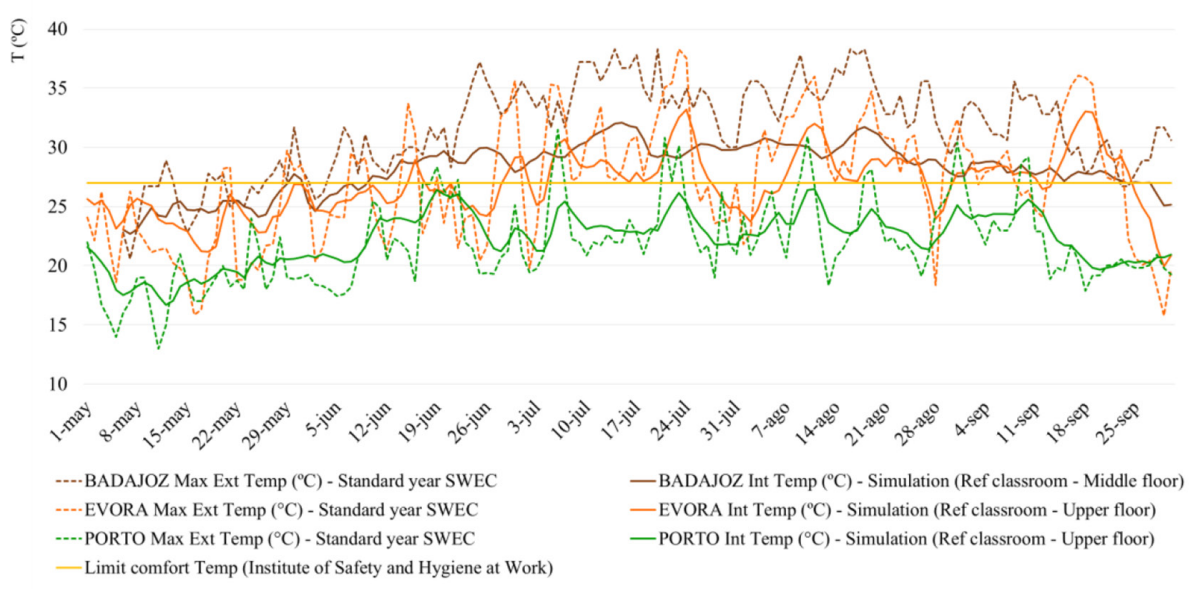

Figure 5: Maximum indoor daily temperature data predicted (without occupation and with no ventilation protocols) versus maximum outdoor temperature data (standard year_US DOE EPW).

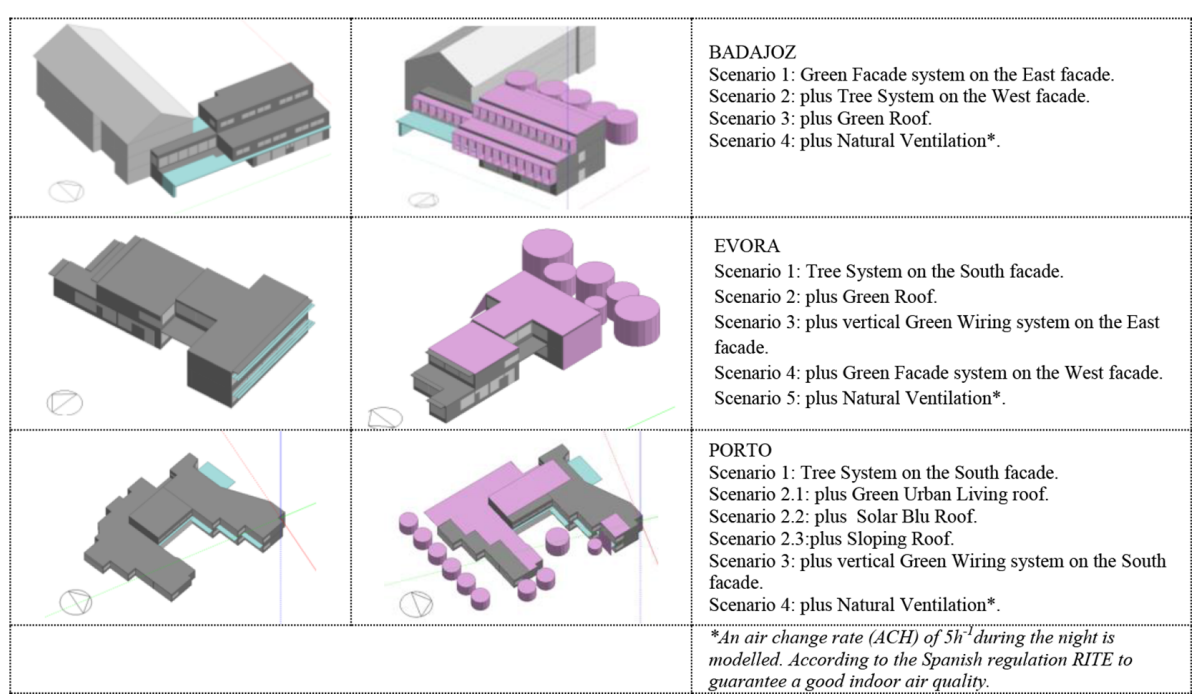

Figure 6: Energy models for the three buildings located in Badajoz, Evora and Porto. On the left, current state (Scenario 0). On the right, the NBS incorporation (Scenarios 1 to 4/5). (Source: authors' formulation using Design Builder 4.7).

Component blocks were used to simulate shading for the different scenarios. They are "solid" blocks that do not generate thermal zones (they do not conduct heat). The blocks allow the wind passing through.

The consideration of the surroundings is included in all the models. The thermal characterisation of the envelope is simulated as described below.

Regarding the airtightness, no mechanical ventilation nor daily natural ventilation are defined. Infiltrations are considered by a typical air change rate of $0.7 \mathrm{~h}^{-1}[10]$. 
This paper is part of a LIFE Project that deals with comfort in schools during heat waves. The two main indicators of the Project are temperature and cooling energy demand reduction. Both are used before and after the NBS intervention, to monitor the improvements they imply.

Indoor temperature and cooling demand analysis are run from May to the end of September, as shown in Fig. 3. Indoor temperature results for the different scenarios are taken from the middle floor to compare with data from the monitored classroom. The whole building's cooling demand is also assessed. The cooling system was simulated as an electric standard cooling system with operating coefficient of $100 \%$.

The NBS proposals for each location analysed in this paper are based on the bioclimatic requirements described previously with the psychrometric abacuses. These different NBS implementation scenarios are introduced consecutively by addition in the three models.

Each of the three building is modelled considering every floor as a separate zone. Occupancy of $0.3 \mathrm{p} / \mathrm{m}^{2}$ is considered.

\section{RESULTS AND DISCUSSION}

This section shows the results of the most appropriate NBS interventions in each case study. This is evidenced by energy modelling of different implementation scenarios. The information obtained here would be valuable for future studies of similar conditions.

Indoor temperature reduction results are given, due to NBS shading techniques. Also, actual cooling demand is analysed to compare NBS reduction potential.

\subsection{Indoor temperature}

As shown in Fig. 7, the improvement in indoor temperature reduction is remarkable when all the NBS scenarios are implemented. Every colour represents temperature percentage reduction relative to the current state temperature (Scenario 0). Mean temperatures from May to September are represented.

Figure 7 and Table 3 illustrate indoor temperature reduction resulting from the application of all scenarios in each location.

In the case of Badajoz, the largest reduction occurs by the incorporation of NBS-Green façade (Scenario 1). The orientation of the building causes thermal stress due to overheating during the mornings (east facade) and in the afternoon (west facade). The implementation of NBS on the roof, from Scenario 2 to 3 , seems to produce smaller impact in temperature.

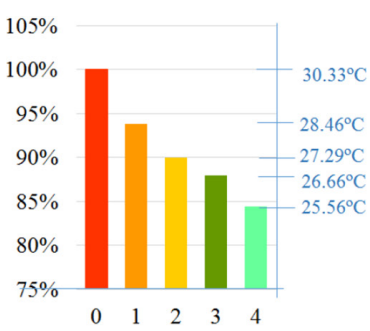

(a)

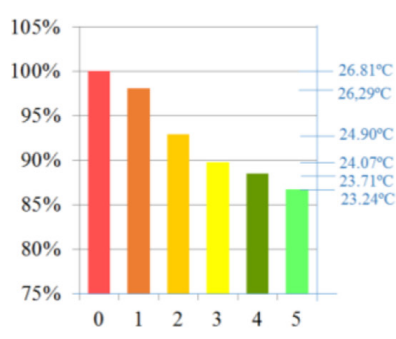

(b)

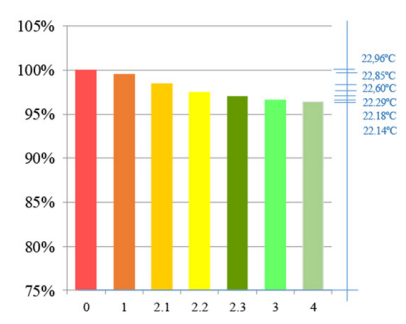

(c)

Figure 7: Mean temperature reduction, after introducing the scenarios in the model. Simulation from May to September. (a) Badajoz, (b) Evora and (c) Porto. (source: authors' formulation) 
Table 3: Reduction of indoor mean temperature $\left(\%\right.$ and $\left.{ }^{\circ} \mathrm{C}\right)$ for each scenario referred to the current state (Scenario 0).

BADAJOZ
\begin{tabular}{|l|cc|c|c|c|c|c|c|}
\hline Month & Scenario 1 & \multicolumn{3}{c|}{ Scenario 2 } & \multicolumn{3}{c|}{ Scenario 3 } & \multicolumn{3}{c|}{ Scenario 4 } \\
& $\%$ & ${ }^{\circ}$ C less & $\%$ & ${ }^{\circ}$ C less & $\%$ & ${ }^{\circ}$ C less & $\%$ & ${ }^{\circ}$ C less \\
\hline May & $\mathbf{9 4 , 1 7 \%}$ & 1,51 & $\mathbf{8 9 , 3 8 \%}$ & 2,76 & $\mathbf{8 7 , 7 2} \%$ & 3,19 & $\mathbf{8 7 , 6 0 \%}$ & 3,22 \\
June & $\mathbf{9 3 , 7 7 \%}$ & 1,87 & $\mathbf{9 0 , 0 3 \%}$ & 2,99 & $\mathbf{8 7 , 9 9 \%}$ & 3,60 & $\mathbf{8 5 , 3 2 \%}$ & 4,41 \\
July & $\mathbf{9 3 , 1 0 \%}$ & 2,27 & $\mathbf{8 9 , 1 0 \%}$ & 3,59 & $\mathbf{8 6 , 7 6 \%}$ & 4,36 & $\mathbf{8 1 , 4 8 \%}$ & 6,10 \\
August & $\mathbf{9 3 , 4 1 \%}$ & 2,17 & $\mathbf{8 9 , 5 1 \%}$ & 3,45 & $\mathbf{8 7 , 1 2 \%}$ & 4,23 & $\mathbf{8 1 , 6 5 \%}$ & 6,03 \\
September & $\mathbf{9 4 , 7 8 \%}$ & 1,56 & $\mathbf{9 1 , 8 4} \%$ & 2,44 & $\mathbf{9 0 , 0 4} \%$ & 2,98 & $\mathbf{8 6 , 2 4 \%}$ & 4,11 \\
\hline
\end{tabular}

\begin{tabular}{|c|c|c|c|c|c|c|c|c|c|c|}
\hline \multicolumn{11}{|l|}{ EVORA } \\
\hline \multirow[t]{2}{*}{ Month } & \multicolumn{2}{|c|}{ Scenario 1} & \multicolumn{2}{|c|}{ Scenario 2} & \multicolumn{2}{|c|}{ Scenario 3} & \multicolumn{2}{|c|}{ Scenario 4} & \multicolumn{2}{|c|}{ Scenario 5} \\
\hline & $\%$ & ${ }^{\circ} \mathrm{C}$ less & $\%$ & ${ }^{\circ} \mathrm{C}$ less & $\%$ & ${ }^{\circ} \mathrm{C}$ less & $\%$ & ${ }^{\circ} \mathrm{C}$ less & $\%$ & ${ }^{\circ} \mathrm{C}$ less \\
\hline May & $98,00 \%$ & 0,48 & $92,11 \%$ & 1,90 & $88,54 \%$ & 2,77 & $87,81 \%$ & 2,95 & $84,87 \%$ & 3,65 \\
\hline June & $98,26 \%$ & 0,45 & $92,74 \%$ & 1,89 & $89,33 \%$ & 2,78 & $88,01 \%$ & 3,12 & $86,17 \%$ & 3,60 \\
\hline July & $98,69 \%$ & 0,37 & $92,79 \%$ & 2,04 & $89,26 \%$ & 3,04 & $87,24 \%$ & 3,61 & $86,60 \%$ & 3,79 \\
\hline August & $98,35 \%$ & 0,46 & $93,44 \%$ & 1,82 & $90,44 \%$ & 2,66 & $88,62 \%$ & 3,16 & $88,02 \%$ & 3,33 \\
\hline September & $97,06 \%$ & 0,82 & $93,26 \%$ & 1,87 & $91,12 \%$ & 2,46 & $90,49 \%$ & 2,64 & $87,46 \%$ & 3,48 \\
\hline
\end{tabular}

\begin{tabular}{|c|c|c|c|c|c|c|c|c|c|c|c|c|}
\hline \multirow{3}{*}{ Month } & \multirow{2}{*}{\multicolumn{2}{|c|}{ Scenario 1}} & \multirow{2}{*}{\multicolumn{2}{|c|}{ Scenario 2.1}} & \multirow{2}{*}{\multicolumn{2}{|c|}{ Scenario 2.2}} & \multirow{2}{*}{\multicolumn{2}{|c|}{ Scenario 2.3}} & \multirow{2}{*}{\multicolumn{2}{|c|}{ Scenario 3}} & \multirow{2}{*}{\multicolumn{2}{|c|}{ Scenario 4}} \\
\hline & & & & & & & & & & & & \\
\hline & $\%$ & ${ }^{\circ} \mathrm{C}$ less & $\%$ & ${ }^{\circ} \mathrm{C}$ less & $\%$ & ${ }^{\circ} \mathrm{C}$ less & $\%$ & ${ }^{\circ} \mathrm{C}$ less & $\%$ & ${ }^{\circ} \mathrm{C}$ less & $\%$ & ${ }^{\circ} \mathrm{C}$ less \\
\hline May & $99,49 \%$ & 0,10 & $98,53 \%$ & 0,30 & $97,71 \%$ & 0,47 & $97,31 \%$ & 0,55 & $96,89 \%$ & 0,64 & $96,89 \%$ & 0,64 \\
\hline June & $\mathbf{9 9 , 5 5 \%}$ & 0,11 & $98,22 \%$ & 0,43 & $97,04 \%$ & 0,72 & $96,44 \%$ & 0,86 & $96,16 \%$ & 0,93 & $95,72 \%$ & 1,03 \\
\hline July & $99,54 \%$ & 0,11 & $98,37 \%$ & 0,38 & $97,40 \%$ & 0,61 & $96,92 \%$ & 0,72 & $96,59 \%$ & 0,79 & $96,41 \%$ & 0,84 \\
\hline August & $99,54 \%$ & 0,11 & $98,45 \%$ & 0,36 & $97,58 \%$ & 0.57 & $97,16 \%$ & 0,67 & $96,63 \%$ & 0,79 & $96,46 \%$ & 0,83 \\
\hline September & $99,51 \%$ & 0,11 & $98,63 \%$ & 0,32 & $97,94 \%$ & 0,48 & $97,59 \%$ & 0,56 & $96,81 \%$ & 0,74 & $96,70 \%$ & 0,77 \\
\hline
\end{tabular}

The simulation of green roofs and green facades is defined as an abstraction of reality. That is why modelling results will always have some shortcomings.

However, in Evora, the roof intervention has the strongest impact. This can be explained by its main facade facing south and this does not affect the demand for cooling as much as the east and west facades. In this case, the reduction in the average indoor temperature is almost $4{ }^{\circ} \mathrm{C}$. From the analysis of results on an hourly basis, specific reductions of more than $6{ }^{\circ} \mathrm{C}$ can be observed in Scenario 5 relative to Scenario 0.

In the case of Porto, the main impact is achieved by the intervention on the roof. The reduction in the average indoor temperature is only $1{ }^{\circ} \mathrm{C}$. If analysed on an hourly basis, some specific reductions of approximately $3{ }^{\circ} \mathrm{C}$ can be observed under Scenario 4 relative to Scenario 0.

\subsection{Analysis of cooling demand reduction}

Figure 8 provides simulation results for cooling demand. The current state (Scenario 0) includes a fictitious standard cooling system for computing the baseline demand (represented as $100 \%)$.

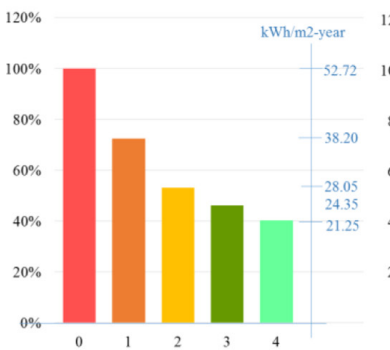

(a)

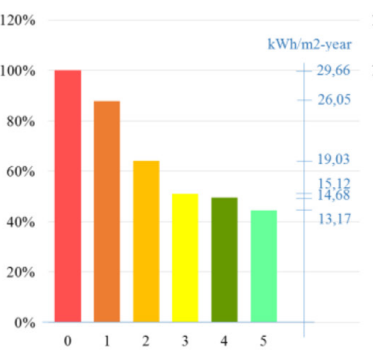

(b)

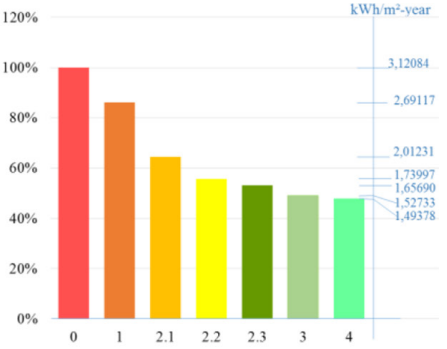

(c)

Figure 8: Annual rate reduction in cooling demand after implementation of NBS. (a) Badajoz, (b) Evora and (c) Porto. (Source: authors'formulation) 
In the case of Badajoz, Scenario 4 reaches up to $40 \%$ of cooling demand reduction. The reduction is very similar in the case of Evora. In both cases, NBS provides a high level of efficiency in the roof solutions in the first place (jump from Scenario 1 to 2), followed by the facade interventions, a jump between Scenario 2 and 4 . The third element that allows a drop in demand of up to $60 \%$ is night ventilation, which is a good complement in the case of Evora, as in Badajoz.

In the case of Porto, it is the solution on deck (jump between Scenario 1 and 3), which stands out above the rest of the interventions. Since Porto has a more humid climate, the solution on the roof reduces the solar radiation provided by the horizontal plane. The rest of the solutions result in small additional reduction complements.

\section{CONCLUSIONS}

In the present paper, the effects of implementing different NBS on energy demand and temperature reduction were assessed through energy simulation software. According to selection of NBS in the three case studies presented, it can be concluded that the solutions are grouped into two large blocks: First, Evora and Badajoz, which represent the hotter and drier climate zones, have similar characteristics and require greater protection both on the roof and on the facades that receive maximum radiation. Passive measures, such as night ventilation and evaporative cooling, are optimal in cost-effective terms. Second, there are the coastal areas of Southern Europe, such as Porto, with milder temperatures and more humidity, where a suitable roofing system that prevents radiation on the horizontal plane is adequate, complemented with minor additional measures such as solar filtering on facades and cross ventilation. In 2021, the LIFE Project will execute the described NBS in the three schools selected. Subsequently, it will take a year of monitoring the indoor environmental conditions. This will serve to contrast the latter with the predictions of the model presented in this paper and be able to make adjustments that would allow the extrapolation of the applied methodology to other European cases.

\section{ACKNOWLEDGEMENTS}

The authors gratefully acknowledge the support of this work by the LIFE+ Programme under the responsibility of the Directorate General for the Environment of the European Commission through the agreement LIFE17 CCA/ES/00088, LIFE myBUILDINGisGREEN.

\section{REFERENCES}

[1] IPCC. AR5 Climate Change 2014: Impacts, Adaptation, and Vulnerability [Internet]. Stockholm, Sweden; 2014 [cited 2020 Feb 21]. Available from: https://www.ipcc.ch/ report/ar5/wg2/

[2] Fermoso, J., Torres, T., Antón, M.A., Peña, A., Muñoz, J., Torre, S., et al., Improvement of classroom conditions and $\mathrm{CO}_{2}$ concentrations through natural ventilation measures reinforced with NBS implementation. 2nd Euro-Mediterranean Conference for Environmental Integration, Tunisia, Paper Number 596, Springer, Oct. 2019.

[3] Gallego, J., Arranz, B., Oteiza, A. \& Martín-Consuegra, F., Hygrothermal comfort and air quality assessment in public schools in Madrid. Study of three cases during a year. Submitted for publication.

[4] Calliari, E., Staccione, A. \& Mysiak, J., An assessment framework for climate-proof nature-based solutions. Science of the Total Environment, 656, pp. 691-700, 2019. https://doi.org/10.1016/j.scitotenv.2018.11.341 
[5] Panno, A., Carrus, G., Lafortezza, R., Mariani, L. \& Sanesi, G., Nature-based solutions to promote human resilience and wellbeing in cities during increasingly hot summers. Environmental Research, 159, pp. 249-256, 2017. https://doi.org/10.1016/j. envres.2017.08.016

[6] Xing, Y., Jones, P. \& Donnison, I., Characterisation of nature-based solutions for the built environment. Sustainability, 9(1), 149, 2017. https://doi.org/10.3390/su9010149

[7] Stabile, L., Massimo, A., Canale, L., Russi, A., Andrade, A. \& Dell'Isola, M., The effect of ventilation strategies on indoor air quality and energy consumptions in classrooms. Buildings, 9(5), p. 110, 2019. https://doi.org/10.3390/buildings9050110

[8] Almeida, R.M.S.F., Pinto, M., Pinho, P.G. \& de Lemos, L.T., Natural ventilation and indoor air quality in educational buildings: Experimental assessment and improvement strategies. Energy Efficiency, 10(4), pp. 839-854, 2017. https://link.springer.com/article/10.1007/s12053-016-9485-0

[9] McIvor, A.E., Hewett, M.J., Borges, D.S., Clements, W.S., Domanski, P.A., Evans R.A., et al., ANSI/ASHRAE Standard 62-2001,Ventilation for Acceptable Indoor Air Quality, 2001.

[10] RITE. Reglamento instalaciones térmicas en los edificios [Internet], 2013. [cited 2017 May 22]. Available from http://www.minetad.gob.es/energia/desarrollo/EficienciaEnergetica/RITE/Paginas/InstalacionesTermicas.aspx

[11] Dovjak, M., Slobodnik, J. \& Krainer, A., Consequences of energy renovation on indoor air quality in kindergartens. Building Simulation, 13(3), pp. 691-708, 2020. https://doi. org/10.1007/s12273-020-0613-6

[12] Korsavi, S.S., Montazami, A. \& Mumovic, D. Indoor air quality (IAQ) in naturallyventilated primary schools in the UK: Occupant-related factors. Building and Environment, 180, p. 106992, 2020. https://doi.org/10.1016/j.buildenv.2020.106992

[13] Carratt, A., Kokogiannakis, G. \& Daly, D., A critical review of methods for the performance evaluation of passive thermal retrofits in residential buildings. Journal of Cleaner Production, 263, p. 121408, 2020. https://doi.org/10.1016/j.jclepro.2020.121408

[14] Código Técnico de la Edificación. Documento Básico HS Salubridad, Ministerio de Fomento Secretaría de Estado de Infraestructuras, Transporte y Vivienda Secretaría General de Vivienda Dirección General de Arquitectura, Vivienda y Suelo (testimony of CTE DB HS) 2019. https://www.codigotecnico.org/images/stories/pdf/salubridad/ DBHS.pdf

[15] Sailor, D.J., A green roof model for building energy simulation programs. Energy and Buildings, 40(8), pp. 1466-1478, 2008. https://doi.org/10.1016/j.enbuild.2008.02.001

[16] Marvuglia, A., Koppelaar, R. \& Rugani, B., The effect of green roofs on the reduction of mortality due to heatwaves: Results from the application of a spatial microsimulation model to four European cities. Ecological Modelling, 438, p. 109351, 2020. https://doi. org/10.1016/j.ecolmodel.2020.109351

[17] Teotónio, I., Cabral, M., Cruz, C.O. \& Silva, C.M., Decision support system for green roofs investments in residential buildings. Journal of Cleaner Production, 249, p. 1193665, 2020. https://doi.org/10.1016/j.jclepro.2019.119365

[18] Morakinyo, T.E., Lai, A., Lau, K.K.L. \& Ng, E., Thermal benefits of vertical greening in a high-density city: Case study of Hong Kong. Urban Forestry \& Urban Greening, 37, pp. 42-55, 2019. https://doi.org/10.1016/j.ufug.2017.11.010 
[19] Larsen, S.F., Filippín, C. \& Lesino, G., Modelling double skin green facades with traditional thermal simulation software. Solar Energy, 121, pp. 56-67, 2015. https://doi. org/10.1016/j.solener.2015.08.033

[20] Gómez, G., Frutos, B., Alonso, C., Martín-Consuegra, F., Oteiza, I., Castellote, M.M., et al., Prediction of thermal comfort and energy behaviour through nature-based solutions implementation. Case study in Badajoz (Spain). WIT Transactions on The Built Environment, Eco-Architecture VIII: Harmonisation between Architecture and Nature, WIT Press, vol. 195, pp. 17-27, 2020. https://doi.org/10.2495/ARC200021

[21] Hoelscher, M.-T., Nehls, T., Jänicke, B. \& Wessolek, G., Quantifying cooling effects of facade greening: Shading, transpiration and insulation. Energy and Buildings, 114, pp. 283-290, 2016. https://doi.org/10.1016/j.enbuild.2015.06.047

[22] Palme, M., Privitera, R. \& La Rosa, D., The shading effects of green infrastructure in private residential areas: Building Performance Simulation to support urban planning. Energy and Buildings, 229, p. 110531, 2020. https://doi.org/10.1016/j. enbuild.2020.110531

[23] Hsieh, C.-M., Li, J.-J., Zhang, L. \& Schwegler, B., Effects of tree shading and transpiration on building cooling energy use. Energy and Buildings, 159, pp. 382-397, 2018. https://doi.org/10.1016/j.enbuild.2017.10.045

[24] de Gobierno, Presidencia, Spain, Real Decreto 2429/1979, de 6 de julio, por el que se aprueba la norma básica de edificación NBE-CT-79, sobre condiciones térmicas en los edificios. Boletín Oficial del Estado, vol. 253, pp. 24524-24550. 1979

[25] Ministério das Obras Públicas, Transportes e Comunicações. Portugal. Decreto-Lei n. ${ }^{\circ}$ 40/1990. Regulamento das Características de Comportamento Térmico dos Edifícios.

[26] Givoni, B., Man, Climate \& Architecture, 2nd edition, Applied Science Publishers: London, 483 pp., 1976.

[27] de España, C.D.M., Real Decreto 485/1997, sobre disposiciones mínimas en materia de señalización de seguridad y salud en el trabajo; anexos I, II y III [Internet]. April 1997. Available from https://www.boe.es/buscar/doc.php?id=BOE-A-1997-8668 